\title{
Synthesis, Complexation and Characterization of 1-Phenyl-3-Methyl-4- (p-nitrobenzoyl) Pyrazolone-5(HNPz) and its complexes of Barium(II), Strontium(II) and Zinc(II)
}

\author{
Nneka D. Ekekwe ${ }^{1,}$, Amaka J. Arinze ${ }^{2}$, Lebe A. Nnanna ${ }^{3}$, Chibueze F. Ukpabi ${ }^{1}$, Akuagwu Agwu ${ }^{1}$, \\ Martins O. C. Ogwuegbu ${ }^{2}$
}

\author{
${ }^{1}$ Department of Chemistry, Abia State Polytechnic, P. M. B. 7166, Aba \\ ${ }^{2}$ Department of Industrial Chemistry, Abia State University, P. M. B. 2000, Uturu \\ ${ }^{3}$ Department of Physics/Electronics, Abia State Polytechnic, P. M. B. 7166, Aba \\ nnekadanieleke@yahoo.com
}

\begin{abstract}
Complexes of $\mathrm{Ba}(\mathrm{II}), \mathrm{Sr}(\mathrm{II})$ and $\mathrm{Zn}(\mathrm{II})$ with 1-phenyl-3-methyl-4- (p-nitrobenzoyl) pyrazolone-5(HNPz) have been synthesized and characterized. The $\mathrm{HNPz}$ was prepared from high grade p-nitrobenzoyl chloride and 1-phenyl-3-methyl-5-pyrazolone. The process involved benzoylation of $17.60 \mathrm{~g}(0.10 \mathrm{M})$ 1-phenyl-3-methyl-5-pyrazolone (HPMP) with $14.55 \mathrm{~g}(0.103 \mathrm{M})$ nitrobenzoylchloride. The complexes of $\mathrm{Ba}$ (II), $\mathrm{Sr}$ (II) and $\mathrm{Zn}$ (II) were prepared by dissolving $5 \mathrm{mmol}$ of $\mathrm{BaCl}_{2} \cdot 2 \mathrm{H}_{2} \mathrm{O}, \mathrm{SrCl}_{2} \cdot 6 \mathrm{H}_{2} \mathrm{O}$ and $\mathrm{ZnSO}_{4} \cdot 7 \mathrm{H}_{2} \mathrm{O}$ respectively in $10 \mathrm{mmol}$ of $\mathrm{HNPz}$. The complexing agent and the metal complexes were characterized by elemental analysis, UV-visible and infrared spectroscopies. The results show the complexes to be dihydrated bischelates conforming to a general molecular formula, MLn. $2 \mathrm{H}_{2} \mathrm{O}$, where $\mathrm{L}$ is the 4-acylpyrazolonato ion and $\mathrm{n}$ is the ligand number or oxidation state of metal, $\mathrm{M}(\mathrm{Ba}, \mathrm{Sr}, \mathrm{Zn})$. The study also indicates the formation of octahedral complexes which are presumed to have been formed through the enolic and carbonyl oxygen atoms of the coordination reagent; in which water molecules complete the expected coordination numbers of $\mathrm{Ba}(\mathrm{II}), \mathrm{Sr}(\mathrm{II})$ and $\mathrm{Zn}(\mathrm{II})$.
\end{abstract}

Keywords 1- Phenyl - 3 - Methyl - 4 - (P - Nitrobenzoyl) Pyrazolone - 5, Pyrazolone, Octahedral Complexes, Bischelates, Enolic Oxygen

\section{Introduction}

Pyrazolone, a five-membered-ring lactam, is a derivative of pyrazole that has an additional keto $(=\mathrm{O})$ group. It has a molecular formula of $\mathrm{C}_{3} \mathrm{H}_{4} \mathrm{~N}_{2} \mathrm{O}$. The chemistry of pyrazolone began in 1883 when Knorr reported the first pyrazolone derivative. The reaction of phenyl hydrazine and ethylacetoacetate resulted in novel structure identified in 1887 as 1-phenyl-3-methyl-5-pyrazolone[8]. The Knorr pyrazole synthesis is the reaction of hydrazines with 1,3 dicarbonyl compounds to provide the pyrazole or pyrazolone ring system. The prototype molecule, antipyrine was synthesized for clinical use in 1883 . The pyrazolone nucleus has been known to exist in three tautomeric structures[9].

Structure 1 of Fig. 1 is present in several substituted

* Corresponding author:

nnekadanieleke@yahoo.com (Nneka D. Ekekwe)

Published online at http://journal.sapub.org/chemistry

Copyright (C) 2012 Scientific \& Academic Publishing. All Rights Reserved pyrazolones which are widely known and used as antipyretic agents. All these compounds are characterized by the presence of a phenyl group attached to nitrogen atom in the 1position and a methyl group in 3- position. Phenyl group in 1- position and a methyl group in 3- position seem to be essential for antipyretic activity. Several 4,4- dimethyl derivatives, as well as Pyrazole Blue and tartrazine are derived from formula II whereas from structure III several pyrazolone dyes have been derived.

When pyrazolones were discovered, they were only known as non-steroidal anti-inflammatory agents (or drugs) - NSAID, but in recent times, they are known to exhibit antioxidant, anticancer, antibacterial and several other pharmacological actions $[8,10]$.

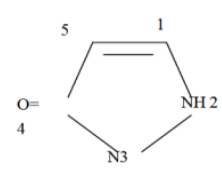

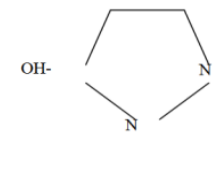

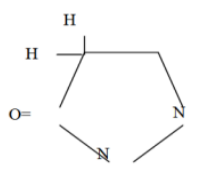

III
Figure 1. Three Tautomeric structures of the Pyrazolone nucleus 
Pyrazolones are very important class of heterocycles due to their wide applications in pharmacological and biological activities[3,6]. Large numbers of 2-pyrazolin-5-ones have been used as therapeutics agents such as analgesics and antipyretics, $[1,2,4]$. It is also well known that they exhibit varied biological activities like anti-inflammatory, antibacterial, antifungal, analgesic, antipyretic, antioxidant, anticonvulsant, antidepressant, antihyperglycemic, antitumor, radioprotectivity, antiviral activities, etc. $[8,10,15]$. 4- acyl pyrazolones form metal chelates that are highly soluble in most organic solvents. They have been found useful as solvent extraction reagents in both acidic and non- acidic me$\operatorname{dia}[5,11]$.

\section{Materials and Methods}

\subsection{Instrumentation}

The FTIR spectra in the range $(4000-400) \mathrm{cm}^{-1}$ were recorded using a Nicolet Spectrophotometer FT 510. The electronic spectra were recorded on a Pye Unicam UV-Visible Specrophotometer SP8-100.

\subsection{Synthesis of I-Phenyl-3-Methyl-4-(p-Nitrobenzoyl)- Pyrazolone-5}

$17.60 \mathrm{~g}(0.10 \mathrm{M})$ of HPMP was dissolved in $75 \mathrm{ml}$ dioxane with gentle warming in a $500 \mathrm{ml}$ three-necked round bottom "quick fit" flask equipped with a magnetic stirrer, separatory funnel and reflux condenser. $7.5 \mathrm{~g}(0.10 \mathrm{M})$ of calcium hydroxide was added to form a paste and then nitrobenzoyl chloride(which had previously been dissolved in $50 \mathrm{ml}$ of dioxane) was added drop wise within 2-5 minutes. The mixture was continuously stirred and gently refluxed for 90 minutes till the yellow calcium complex was formed. It was allowed to cool and the calcium complex decomposed by pouring into $400 \mathrm{ml}$ of chilled $3 \mathrm{M} \mathrm{HCl}$, whereby cream crude nitrobenzoylpyrazolone precipitated. The crude product was recrystallized from an ethanol-water mixture containing a little hydrochloric acid to destroy any undecomposed calcium complex[11,14].

\subsection{Synthesis of Barium(II), Strontium(II) And Zinc(II) Complexes.}

The complexes of $\mathrm{Ba}(\mathrm{II}), \mathrm{Sr}(\mathrm{II})$ and $\mathrm{Zn}(\mathrm{II})$ with $\mathrm{HNPz}$ were prepared by dissolving $5 \mathrm{mmol}$ of the respective reagents $\left(\mathrm{BaCl}_{2} \cdot 2 \mathrm{H}_{2} \mathrm{O}, \mathrm{SrCl}_{2} \cdot 6 \mathrm{H}_{2} \mathrm{O}\right.$ and $\left.\mathrm{ZnSO}_{4} \cdot 7 \mathrm{H}_{2} \mathrm{O}\right)$ in 100 $\mathrm{ml}$ warm water. The solutions were each added dropwise with stirring to a $100 \mathrm{ml}$ hot ethanol solution of $10 \mathrm{mmol}$ $\mathrm{HNPz}$, giving a metal-ligand mole ratio of 1:2.

The mixtures were heated up to $60^{\circ} \mathrm{C}$ and allowed to cool to room temperature whereby precipitates appeared. The precipitates were filtered, washed with aqueous ethanol (2:1) and left in desiccators to dry over fused calcium chloride to yield crystals[7,9].

The chelation process leading to the formation of the metal complexes can be represented as a displacement of protons from ligand molecules as expressed in Equation 1.

$$
\mathrm{M}^{\mathrm{n}+}(\mathrm{aq})+\mathrm{nHL}(\text { org }) \longrightarrow \mathrm{MLn}(\text { org })+\mathrm{nH}^{+}(\mathrm{aq})
$$

\section{Results and Discussion}

Table 1 shows the physical data for the ligand and the synthesized complexes. The calculated values were in a good agreementwith the experimental values.

\subsection{UV-Visible Spectroscopy}

Table 2 shows the electronic spectral data of $\mathrm{HNP}_{\mathrm{z}}$ and the metal complexes. It shows that the ligand and the metal complexes all absorb in the ultraviolet region around $\lambda_{1}=$ $205 \mathrm{~nm}$ for the ligand and $213 \mathrm{~nm}$ for $\mathrm{Ba}(\mathrm{II}), 209 \mathrm{~nm}$ for $\mathrm{Sr}(\mathrm{II})$ and $198 \mathrm{~nm}$ for $\mathrm{Zn}$ (II) complexes. The ligand and the metal complexes appear to have virtually identical spectra.

No band was observed in the visible region for any of the studied M (II) metal complexes, and it is therefore evident that there was no $d$ to $d$ transition in any of these complexes. The observed absorption are ascribed to the intraligand $\pi-\pi^{*}$ transitions[11].

Also the molar absorptivity values which are large (i.e greater than $10^{4} \mathrm{~L} . \mathrm{mol}^{-1} \mathrm{~cm}^{-1}$ ) indicate charge- transfer absorption. Slight bathochromic (red) shift was observed at $\lambda_{1}$ (except for that of $\left.\mathrm{Zn}\left(\mathrm{NP}_{\mathrm{z}}\right)_{2} \cdot 2 \mathrm{H}_{2} \mathrm{O}\right)$ and $\lambda_{2}$ of the metal complexes which indicate chelate formation between $\mathrm{HNP}_{z}$ anion and the metal ions.

The similarity in character of the UV spectrum of the ligand to those of the metal complexes indicate that the $\pi$ bonding system of the free nitrobenzoyl pyrazolone is almost intact in the ligand anion of the metal complexes. Thus, there is no interaction between the $\pi$-bonding system of the ligand and the $\mathrm{Ba}(\mathrm{II}), \mathrm{Sr}(\mathrm{II})$ and $\mathrm{Zn}$ (II) ions respectively. The coordination between the metal ions and the $\mathrm{HNP}_{\mathrm{z}}$ anion therefore, is through $\sigma$-bond formation between respectively, $\mathrm{Ba}(\mathrm{II}), \mathrm{Sr}(\mathrm{II}), \mathrm{Zn}(\mathrm{II})$ and the oxygen atom (O) of the carbonyl group $(\mathrm{C}=\mathrm{O})$ of the ligand as shown in Fig.1.

This is achieved by deprotonation of the hydroxyl group of the ligand and accepting an electron pair from the oxygen atom of the second carbonyl group that did not enolize[13].

\subsection{Infra- Red Spectroscopy}

The FTIR spectral data for the ligand and metal complexes are listed in Table 3.

The observed frequencies and approximate assignments shown in Table 3 have been divided into three main spectral regions; viz, $4000-1800 \mathrm{~cm}^{-1}, 1800-1000 \mathrm{~cm}^{-1}$ and $1000-400$ $\mathrm{cm}^{-1}$.

\subsection{1. $4000-1800 \mathrm{~cm}^{-1}$ region}

All the metal complexes showed broad absorption bands around 3440- $3415 \mathrm{~cm}^{-1}$ region, and have been assigned to $\mathrm{OH}$ of adduct water molecules coordinated to the central metal ions or residing in the crystal lattices of the complexes. This gives further confirmation of the micro analytical results obtained for all the metal complexes. However, the weak band at $3443 \mathrm{~cm}^{-1}$ in the FTIR spectrum of the ligand has been attributed to vibrational frequency mode of $\mathrm{OH}$ of the enolized form of the ligand. The relatively weak bands of 
the metal complexes of $\mathrm{Ba}(\mathrm{II}), \mathrm{Sr}(\mathrm{II})$ and $\mathrm{Zn}(\mathrm{II})$, between 3131 and $3115 \mathrm{~cm}^{-1}$ were assigned to the vibrational stretching frequency mode of $\mathrm{C}-\mathrm{H}$ group of the coordinated neutral $\mathrm{HNP}_{\mathrm{z}}[13]$.

The band at $2555 \mathrm{~cm}^{-1}$ of $\mathrm{Ba}$ (II) complexes is assigned to the vibrational stretching frequency mode of $\mathrm{O}-\mathrm{H}---\mathrm{O}$ and is typical of $\beta$-diketones and diketonates involved in intramolecular hydrogen bonding. The bands between 2367 and $2361 \mathrm{~cm}^{-1}$ of the ligand, $\operatorname{Sr}(\mathrm{II})$ complex and $\mathrm{Zn}(\mathrm{II})$ complex are assigned to the bending or deformation of the O-H group.

The band at $1966 \mathrm{~cm}^{-1}$ of $\mathrm{Ba}(\mathrm{II})$ complex also was assigned to the $\mathrm{BO}-\mathrm{H}$ of water. This further confirms the micro analytical results showing the presence of water in the ligand- metal complexes.

The complete disappearance of the weak band due to $\mathrm{OH}$ group of the ligand in the FTIR spectra of the metal complexes suggests the deprotonation of the $\mathrm{OH}$ group during chelation, and the formation of $\mathrm{M}-\mathrm{O}$ bond,in place of an $\mathrm{OH}$ bond in the metal complexes. This further supports the view that the only interaction between $\mathrm{M}(\mathrm{II})$ ions and the ligand resulted in sigma bond formation between M(II) ions and the oxygen atoms of the ligand.

\subsection{2. $1800-1000 \mathrm{~cm}^{-1}$ region}

The absorption band around $1700 \mathrm{~cm}^{-1}$ in the FTIR spectrum of the ligand is assigned to symmetric carbonyl vibrations ${ }_{\mathrm{V}} \mathrm{C}=\mathrm{O}$. The assignments also show a shift of the ${ }_{\mathrm{V}} \mathrm{C}=\mathrm{O}$ from $1699.63 \mathrm{~cm}^{-1}$ recorded for $\mathrm{HNPz}$, to a strong band appearing at a higher frequency at $1701 \mathrm{~cm}^{-1}$ for zinc metal complex, suggesting that the $\mathrm{C}=\mathrm{O}$ group is involved in chelation and that the chelation process is essentially that of displacement of $\mathrm{H}$ ions of the ligand by the metal ion, and the formation of the $\mathrm{C}=\mathrm{O}-\mathrm{M}$ bonding system by the reaction of the type:

$$
\left.\mathrm{M}^{\mathrm{n}+}\left(_{\text {aq }}\right)+\mathrm{nHNP}_{(\text {org }}\right) \rightarrow \mathrm{M}(\mathrm{NP})_{\mathrm{n}}(\text { org })+\mathrm{nH}^{+}\left({ }_{\mathrm{aq}}\right)
$$

Where $\mathrm{n}$ is the number of ligands involved[13].

The absorption band at around $1542-1520 \mathrm{~cm}^{-1}$ in the IR spectra of both ligand and M (II) complexes were assigned to pyrazole stretching vibrational frequency. The observed shifts of the bands of the M(II) complexes from that of the ligand is an evidence that the pyrazole ring with its $-\mathrm{C}=\mathrm{C}$ group is involved in the chelation process through electron delocalization of the chelate ring as shown in Figure 1.

The vibrational frequency modes between 1117- 1103

$\mathrm{cm}^{-1}$ have been assigned to $\mathrm{C}-\mathrm{H}$ in-plane deformation of the phenyl ring in the complexes. A comparism of the spectrum of the ligand with those of the metal complexes show that there is little or no shift in the above frequencies, indicating that the $\pi$ system of the monosubstituted phenyl ring of the free ligand is not involved in the coordination with metal ions studied[12].

\subsection{3. $1000-400 \mathrm{~cm}^{-1}$ region}

The most important vibrational frequency modes in this region are those due to the chelate ring and metal-ligand vibrations. This region provides information on the effect of 4-acyl substituent on the stability of the metal-oxygen bond.

The vibrational frequencies between 926 and $921 \mathrm{~cm}^{-1}$ are ascribed to $\mathrm{CH}_{3}$ rocking or $\mathrm{C}-\mathrm{Ph}$ stretch. Those around $863-849 \mathrm{~cm}^{-1}$ are ascribed to $\mathrm{O}=\mathrm{M}=\mathrm{O}$ vibrations. The $\mathrm{ab}-$ sorption bands between 663 and $507 \mathrm{~cm}^{-1}$ are due to metal-oxygen and chelate ring vibrations. The absence of the 624-605 $\mathrm{cm}^{-1}$ (assigned to $\mathrm{M}-\mathrm{O}+$ chelate ring vibrations) in the IR spectrum of the ligand signifies chelation. It appeared in the complexes due to chelation.

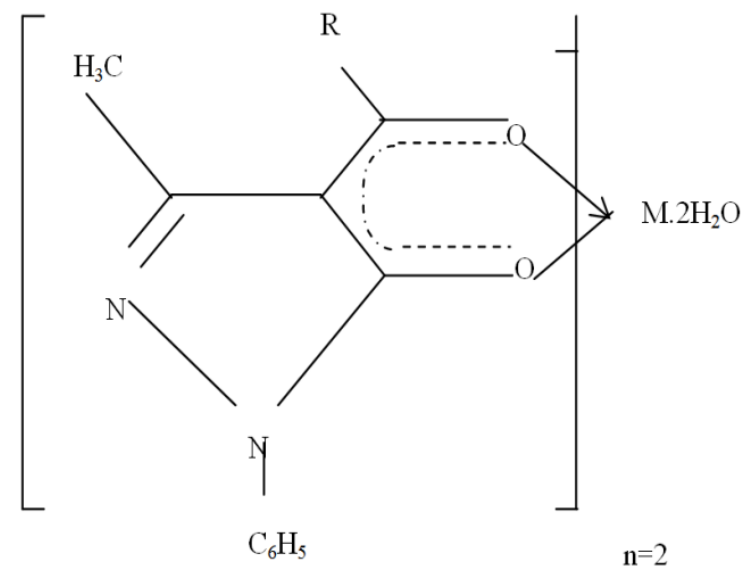

Figure 2. Metal Complex, $\mathrm{M}=\mathrm{Ba}(\mathrm{II}), \mathrm{Sr}(\mathrm{II}), \mathrm{Zn}(\mathrm{II})$

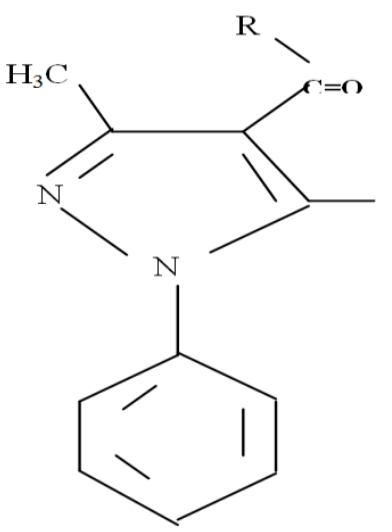

OH

Figure 3. Ligand structure

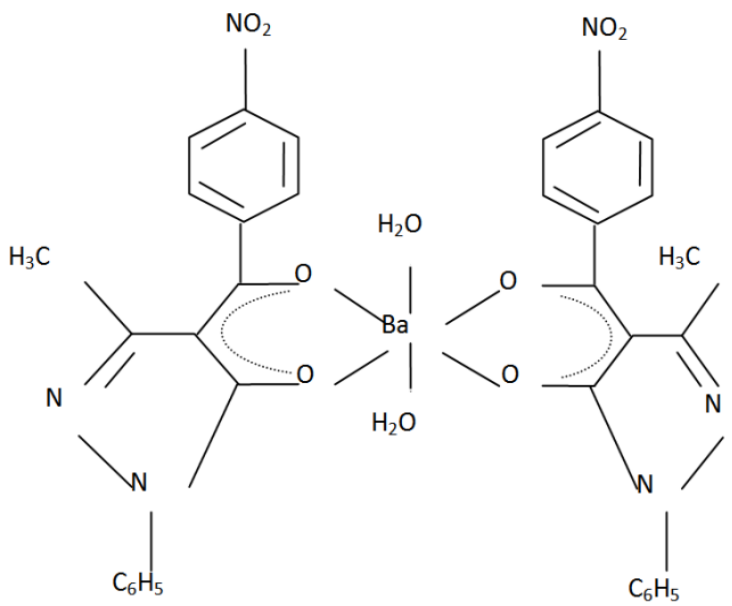

Figure 4. Bis (1-phenyl-3- methyl -4- (p-nitrobenzoyl) pyrazolonato) diaquobarium (II). $\mathrm{Ba}(\mathrm{NPz})_{2} 2 \mathrm{H}_{2} \mathrm{O}$ 


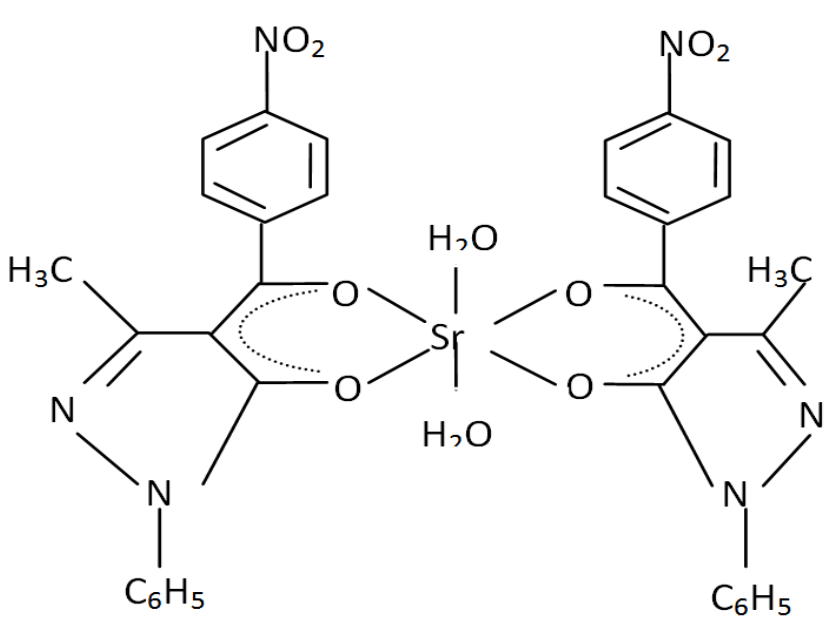

Figure 5. Bis (1-phenyl-3- methyl -4- (p-nitrobenzoyl) pyrazolonato) diaquostrontium (II). $\mathrm{Sr}(\mathrm{NPz})_{2} 2 \mathrm{H}_{2} \mathrm{O}$

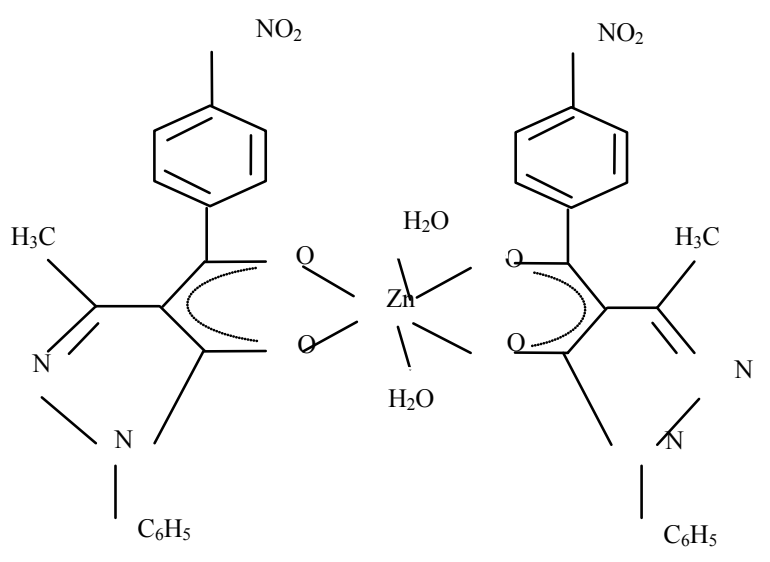

Figure 6. Bis (1-phenyl-3- methyl -4- (p-nitrobenzoyl) pyrazolonato) diaquozinc (II). $\mathrm{Zn}(\mathrm{NPz})_{2}, 2 \mathrm{H}_{2} \mathrm{O}$

Table 1. Physical and Elemental Analyses Data for HNPz, (Ba(II), Sr(II) and Zn(II) complexes

\begin{tabular}{|c|c|c|c|c|c|c|c|}
\hline Compound & Molecular Formula & Color & Melting point $\left({ }^{\circ} \mathrm{C}\right)$ & Yield & $\%$ Found (\% cald ) $\mathrm{C}$ & $\mathrm{H}$ & $\mathrm{N}$ \\
\hline $\mathrm{HNP}_{\mathrm{Z}}$ & $\mathrm{C}_{17} \mathrm{H}_{13} \mathrm{~N}_{3} \mathrm{O}_{4}$ & Cream & 165 & $84 \%$ & $\begin{array}{c}63.06 \\
(63.16) \\
\end{array}$ & $\begin{array}{c}4.12 \\
(4.02) \\
\end{array}$ & $\begin{array}{r}13.04 \\
(13.00) \\
\end{array}$ \\
\hline $\mathrm{Ba}\left(\mathrm{NP}_{\mathrm{z}}\right)_{2} \cdot 2 \mathrm{H}_{2} \mathrm{O}$ & $\mathrm{BaC}_{34} \mathrm{H}_{28} \mathrm{~N}_{6} \mathrm{O}_{10}$ & $\begin{array}{l}\text { Bone } \\
\text { White }\end{array}$ & 120 & $92 \%$ & $\begin{array}{c}49.86 \\
(49.94) \\
\end{array}$ & $\begin{array}{c}3.38 \\
(3.43) \\
\end{array}$ & $\begin{array}{r}10.39 \\
(10.28) \\
\end{array}$ \\
\hline $\mathrm{Sr}\left(\mathrm{NP}_{\mathrm{z}}\right)_{2} \cdot 2 \mathrm{H}_{2} \mathrm{O}$ & $\mathrm{SrC}_{34} \mathrm{H}_{28} \mathrm{~N}_{6} \mathrm{O}_{10}$ & Orange & 161 & $86 \%$ & $\begin{array}{c}53.20 \\
(53.13) \\
\end{array}$ & $\begin{array}{c}3.50 \\
(3.65) \\
\end{array}$ & $\begin{array}{r}11.03 \\
(10.94) \\
\end{array}$ \\
\hline $\mathrm{Zn}\left(\mathrm{NP}_{\mathrm{z}}\right)_{2} \cdot 2 \mathrm{H}_{2} \mathrm{O}$ & $\mathrm{ZnC}_{34} \mathrm{H}_{28} \mathrm{~N}_{6} \mathrm{O}_{10}$ & $\begin{array}{c}\text { Dull } \\
\text { Yellow } \\
\end{array}$ & 310 & $86 \%$ & $\begin{array}{c}54.69 \\
(54.77) \\
\end{array}$ & $\begin{array}{c}3.80 \\
(3.76) \\
\end{array}$ & $\begin{array}{r}11.20 \\
(11.28) \\
\end{array}$ \\
\hline
\end{tabular}

Table 2. Electronic Spectral Data For $\mathrm{HNP}_{\mathrm{z}}$ and Metal Complexes

\begin{tabular}{|c|c|c|c|c|c|c|}
\hline Compound & $\lambda_{1} \max (\mathrm{nm})$ & $\mathrm{E}_{1}\left(\mathrm{~L} \cdot \mathrm{mol}^{-1} \mathrm{~cm}^{-1}\right)$ & $\lambda_{2} \max (\mathrm{nm})$ & $\mathrm{E}_{2} \mathrm{~L} \cdot \mathrm{mol}^{-1} \mathrm{~cm}^{-1}$ & $\lambda_{3} \max (\mathrm{nm})$ & $\mathrm{E}_{3} \mathrm{~L} \cdot \mathrm{mol}^{-1} \mathrm{~cm}^{-}$ \\
\hline $\mathrm{HNP}_{\mathrm{z}}$ & 205 & $7.5 \times 10^{3}$ & 265 & $1.2 \times 10^{4}$ & - & - \\
\hline $\mathrm{Ba}-\mathrm{NP}_{\mathrm{z}}$ & 212.5 & $9.25 \times 10^{4}$ & 245 & $3.3 \times 10^{4}$ & 262.5 & $2.6 \times 10^{4}$ \\
\hline $\mathrm{Sr}-\mathrm{NP}_{\mathrm{z}}$ & 208.5 & $5.6 \times 10^{4}$ & 240 & $2.4 \times 10^{4}$ & 265 & $1.9 \times 10^{4}$ \\
\hline $\mathrm{Zn}-\mathrm{NP}_{\mathrm{z}}$ & 198 & $1.11 \times 10^{6}$ & 246 & $3.4 \times 10^{5}$ & 265 & $2.9 \times 10^{5}$ \\
\hline
\end{tabular}

Table 3. The Infrared Spectral Data for $\mathrm{HNP}_{\mathrm{z}}$ and Metal Complexes and Their Approximate Assignments

\begin{tabular}{|c|c|c|c|c|}
\hline $\mathrm{HNP}_{\mathrm{Z}}$ & $\mathrm{Ba}$ (II) Complex & Sr(II) Complex & Zn(II) Complex & Assignments \\
\hline- & $3440 \mathrm{~b}$ & $3415 b$ & $3422 b$ & ${ }_{\mathrm{v}} \mathrm{OH}$ of water \\
\hline $3443 b$ & - & - & - & $\mathrm{v} \mathrm{OH}$ of enol \\
\hline $3060 w$ & $3131 w$ & $3116 w$ & $3115 \mathrm{w}$ & ${ }_{\mathrm{v}} \mathrm{C}-\mathrm{H}$ \\
\hline- & $2555 \mathrm{~W}$ & - & - & vO-H---O \\
\hline $2366 \mathrm{w}$ & - & $2367 \mathrm{~m}$ & $2361 \mathrm{~m}$ & $\beta \mathrm{O}-\mathrm{H}$ \\
\hline- & $1966 \mathrm{w}$ & - & - & $\beta \mathrm{O}-\mathrm{H}$ of water \\
\hline $1700 \mathrm{~s}$ & - & - & $1701 \mathrm{vs}$ & ${ }_{\mathrm{v}} \mathrm{C}=\mathrm{O}$ \\
\hline $1622 \mathrm{~s}$ & $1697-1623 \mathrm{~s}$ & $1694-1622 \mathrm{vs}$ & 1609 & vas $\mathrm{C}---\mathrm{O}$ \\
\hline \multirow[t]{2}{*}{$1522 \mathrm{~m}$} & $1522 \mathrm{~s}$ & $1520 \mathrm{~m}$ & $1542 \mathrm{~m}$ & vas $\mathrm{C}=\mathrm{C}=\mathrm{C}$ \\
\hline & & & & Phenyl ring \\
\hline- & $1431 \mathrm{~s}$ & $1431 \mathrm{~s}$ & - & $\mathrm{Bas} \mathrm{CH}_{3}$ \\
\hline $1341 \mathrm{~s}$ & $1349 \mathrm{vs}$ & $1350 \mathrm{vs}$ & 1351vs & vs $\mathrm{C}=\mathrm{O}$ \\
\hline $1211 \mathrm{~s}$ & $1295-1211 \mathrm{~s}$ & $1284 \mathrm{~m}$ & $1293 \mathrm{~m}$ & $\beta \mathrm{C}-\mathrm{H}$ \\
\hline $1110 \mathrm{~s}$ & $1115 \mathrm{w}$ & $1117 \mathrm{~s}$ & $1112 \mathrm{w}$ & $\mathrm{C}-\mathrm{H}$ in plane \\
\hline- & - & - & $1015 \mathrm{~m}$ & deformation of monosubstituted phenyl ring \\
\hline $921 \mathrm{~s}$ & $921 \mathrm{~s}$ & $926 \mathrm{~s}$ & - & C-Ph stretch \\
\hline $849 m$ & $849 m$ & - & $863 \mathrm{~m}$ & $\mathrm{O}=\mathrm{M}=\mathrm{O}$ \\
\hline $744-717 \mathrm{~m}$ & $744-717 \mathrm{vs}$ & $717 \mathrm{vs}$ & $717 \mathrm{vs}$ & $\gamma \mathrm{C}-\mathrm{H}$ \\
\hline- & $605 \mathrm{~s}$ & - & $663-624 w$ & $\gamma \mathrm{M}-\mathrm{O}+$ chelate ring deformation \\
\hline $596 \mathrm{~s}$ & $517 \mathrm{~s}$ & $598-510 \mathrm{w}$ & $507 \mathrm{~W}$ & Chelate ring vibrations \\
\hline $465 \mathrm{w}$ & - & $456 \mathrm{w}$ & $453 w$ & vM-O \\
\hline
\end{tabular}




\section{Conclusions}

The combination of data from elemental analysis, UV-visible and IR spectroscopic studies reveal that the p-nitrobenzoyl pyrazolone forms complexes with all the metal ions studied, and that their structures conform to the octahedral geometry proposed, as shown in figures 4,5 and 6 wherein water molecules take up two positions of the octahedron as is evident in Table 1. The bonds between $\mathrm{HNPz}$ and a metal ion are formulated as $\sigma$-bonds formed through the carbonyl and hydroxyl groups of the keto-enol form of the ligand.

\section{REFERENCES}

[1] Abdel - Aziz, M., Abuo-Rahma, G.E.A and Hasan, A.A. (2009). Synthesis of novel pyrazole derivatives and evaluation of their antidepressant and anticonvulsant activities, Eur. J. Med. Chem., 44., 3480-3487.

[2] Brune, M.D.K. (1997). "The early history of non- opioid analgesics", Acute Pain, 1 (1),33-40.

[3] Das, N., Verma, A., Strivastava, P.K and Shrivastava, S.K. (2008). Synthesis and biological evaluation of some new aryl pyrazol -3- one derivatives as potential hypoglycemic agents, Ind. J. Chem., 47B, 1555-1558.

[4] Georgewill, O.A, Georgewill, U.O and Nwankwoala, R.N.P (2009). "Antiinflammatory activity of a new pyrazolone drug", The Internat. J. of Pharmacol., 7(1), 220-225.

[5] Housecroft, C.E, Sharpe, A.G (2008). Inorganic chemistry, $3^{\text {rd }}$ edition, Prentice Hall, New Jersey, pp. 305-306.

[6] Kees, K.L., Fitzgerald, J.J., Steiner, K.E., Mattes, J.F., Mihan, B., Tosi, T., Mondoro, D. and McCaleb, M.L. (1996). New potent antihyperglycemic agents in mice: Synthesis and structure- activity relationship studies of (4-substituted benzyl)(trifluoromethyl) pyrazoles and pyrazolones, J. Med.
Chem., 39, 3920-3928.

[7] Kees, K.L., Fitzgerald, Jr. J.J., Steiner, K.E., Mattes, J.F., Mihan, B., Tosi, T., Mondoro, D and McCaleb, M.L. (1996). Synthesis of pyrazolone derivatives. J. Med. Chem., 39, 3920.

[8] Knorr, L. (1883). Einwirkung von Acetessigester auf Hydrazinchinizin derivative. Chem. Ber., 17, 546-552.

[9] Mariappan G., Saha B.P, Sutharson L, Ankits, G., Pandey, L and Kumar, D.(2010). The Diverse Pharmacological importance of Pyrazolone Derivatives: A Review. Journal of Pharmacy Research, vol.3 (12). pp 2856-2859.

[10] Maywald, V., Steinmetz, A., Rack, M., Gotz, N., Gotz, R., Henkelmann, J. and Becker, H. (2000). Synthesis of pyrazolones. Aiscar Bayeto, PCT Int. Appl. WO 0031042 A2 (Chem. Abstr., 133, 4655).

[11] Min, J.S., Jung, K.K., Bum, S.S., Bo, G.S., Zaesung, N., Hyae, G.C., Kwang-Rok, K., Young, S.S and Hyoung, R.K. (2004). Novel 3-methyl-4- (O-substituted-oximino)-Pyrazolin-5-ones as a potent Inhibitor of Cdc 25B Phosphatase, Bull. Korean. Chem. Soc., 25(8), 1121.

[12] Ogwuegbu, M.O.C and Maseka, K.K (1998). Studies on the Coordination Complexes of $\mathrm{Ca}(\mathrm{II}), \mathrm{Cd}(\mathrm{II})$ and $\mathrm{Tn}(\mathrm{IV})$ with p-Nitrobenzoyl-oxo-pyrazole, Bull. Chem. Soc. Ethiop., 12(1), 27-33

[13] Ogwuegbu, M.O.C. and Chileshe, F. (2000). Coordination Chemistry In Mineral Processing, Min. Proc. Extr. Met. Rev., (21), 497-503.

[14] Okafor E. C. and Uzoukwu B.A (1993). Adduct coordination in U (VI) complexes of 1-phenyl-3-methyl-pyrazolone-5: UV, IR and NMR spectral studies, Synth. React. Inorg. Met. Org. Chem.,23(1), 85-95.

[15] Uzoukwu B.A (1990). Metal complexes of $\beta$-diketones: synthesis, ultraviolet and infrared spectral studies of Nickel(II) complexes of 1-phenyl-3-methyl-4-acyl-pyrazolone-5, Synth. React. Inorg. Met. Org. Chem.,20(8), 1071-1084.

[16] Yamamoto, Y., Kuwahara, T. and Watanabe, K. (1996). "Antioxidant activity of 3- methyl-1 -phenyl -2- pyrazolin5- one, Redox Report 2, 333-338. 